\title{
Effect of Co- existing Filamentous Fungi on Growth Inhibition and Aflatoxin production by Aspergillus parasiticus
}

\author{
Byas Kumar', Baidyanath Kumar ${ }^{2 *}$, Soniya Bharti ${ }^{1}$ and Jainendra Kumar ${ }^{3}$ \\ ${ }^{1}$ Department of Biotechnology, College of Commerce, Arts and Science (Magadh University), \\ Patna- 800020, Bihar, India \\ ${ }^{2}$ Department of Biotechnology, Patna Science College (Patna University), \\ Patna- 800005, Bihar, India \\ ${ }^{3}$ Department of Botany, College of Commerce, Arts and Science (Magadh University), \\ Patna- 800020, Bihar, India \\ *Corresponding author
}

\section{A B S T R A C T}

Aflatoxin belongs to a group of fungal toxins known as mycotoxins. It poses a potential threat to food safety. As aflatoxin is epidemiologically implicated as carcinogen in humans and an environmental contaminant which is widespread in nature, its possible chronic toxicity is therefore of greater concern than acute toxicity. It is a secondary metabolite produced by specific strains of Aspergillus. Aflatoxin is classified into a number of subtypes. However, the most important ones are B1, B2, G1 and G2, distinguished by their fluorescence colour under ultraviolet light. In the present investigation the influence of microbial interactions on growth and aflatoxin production by a toxigenic strain of Aspergillus parasiticus NRRL2999 in vitro was studied. The results clearly indicated that all the fifteen types of interacting fungi were found to inhibit growth and aflatoxins B1, B2, G1 and G2 production by Aspergillus parasiticus NRRL2999 strain but the intensity was variable. It is evident that $1 \mathrm{ml}$ of culture filtrate of Alternaria alternata, A. brassicae, Helminthosporium sativum, Chaetomium globosum, Cladosporium herbarum, Fusarium moniliforme, Penicillium citrinum, Mucor mucedo, Rhizopus stolonifer and R. nigricans was found to be highly inhibitory to growth of A. parasiticus NRRL2999 that caused $57.47 \%$ to $76.55 \%$ inhibition. The results confirm that all the fifteen interacting fungi viz. Aspergillus niger, A. sydowi, Alternaria alternata, A. brassicae, Curvularia lunata, Geotrichum candidum, Monilia sitophila, Helminthosporium sativum, Chaetomium globosum, Cladosporium herbarum, Fusarium moniliforme, Penicillium citrinum, Mucor mucido, Rhizopus nigricans and Rhizopus stolonifer are the best biological agents to inhibit growth and Aflatoxin production ability of Aspergillus parasiticus NRRL2999 strain.

\section{Introduction}

Aflatoxin belongs to a group of fungal toxins known as mycotoxins. It was discovered some 30 years ago in England following a poisoning outbreak causing 100,000 turkey deaths. Mycotoxins have received considerable attention due to their significance in agricultural loss and human health. Amongst the mycotoxins that are known to cause human diseases, aflatoxins have been studied most. Aflatoxin poses a potential threat to food safety. As aflatoxin is epidemiologically implicated as carcinogen in 
humans and an environmental contaminant which is widespread in nature, its possible chronic toxicity is therefore of greater concern than acute toxicity.

Aflatoxin is the secondary metabolite produced by specific strains of Aspergillus. These species contaminate various agricultural commodities either before harvest or at post-harvest stages under favourable conditions of temperature and humidity.

Aspergillus is a large genus of mould which grows at an optimal range of temperature of $28-33^{\circ} \mathrm{C}$ and at the water activity of about 0.83-0.97. The aflatoxigenic moulds, namely A flavus, $A$ parasiticus and $A$ nomius are principally found in soils and decaying vegetation. They occur in warmer parts of the world such as tropical region where temperature and moisture are high. They have a higher affinity of growth in nuts and oilseeds. Aflatoxin is classified into a number of subtypes. However, the most important ones are B1, B2, G1 and G2, distinguished by their fluorescence colour under ultraviolet light. In addition, aflatoxin M1 and M2 are hydroxylated metabolites of aflatoxin B1 and B2. Aflatoxins are odourless, tasteless and colourless. Chemically, they are stable in foods and resistant to degradation under normal cooking procedures. It is difficult to eliminate aflatoxin once it is produced.

Accumulation of aflatoxin is dependent upon weather conditions. Before harvest, the risk for the development of aflatoxin is greatest during major droughts. When soil moisture is below normal and temperatures are high, the number of Aspergillus spores in the air increases. These spores infect crops through areas of damage caused by insects, and inclement weather. Once infected, plant stress occurs, the production of aflatoxin is favoured. During post-harvest stage, proliferation of aflatoxin can be exacerbated in susceptible commodities under storage conditions such as hot and humid storage environment.

Human exposure to aflatoxin is principally through ingestion of contaminated foods. Inhalation of the toxins may also occur occasionally due to the occupational exposure. Aflatoxin can cause both acute and chronic toxicity in animals. Effects such as acute liver damage, liver cirrhosis, induction of tumors and teratogenic and other genetic effects are well documented.

The acute toxicity of aflatoxin to humans has been encountered only rarely. Symptoms may include fever, vomiting and jaundice. Acute liver damage can occur which may be fatal in severe cases. There has not been any food poisoning case related to dietary aflatoxin. Long term intake of aflatoxin can be associated with hepatic cancer. Animal studies have showed that hepatocellular liver tumors may develop in animals like rats, hamsters and monkeys after prolonged oral administration. Epidemiological studies supported a positive correlation between the logarithm of aflatoxin ingestion and the occurrence of human primary liver cancer. Studies revealed that the co-existence of hepatitis B virus infection might contribute to higher incidence of liver cancer in aflatoxin exposed populations.

Mycotoxins have detrimental effects, so a number of strategies have been developed to help prevent the growth of mycotoxigenic fungi as well as to decontaminate and/or detoxify mycotoxin contaminated foods and animal feeds. These strategies include the prevention of mycotoxin contamination, detoxification of mycotoxins present in food and feed and inhibition of mycotoxin absorption in the gastrointestinal tract. The prevention of mycotoxin contamination prior to harvest or during post-harvest and storage 
is not always possible necessitating decontamination before the use of such materials for food and feed purposes. Therefore various detoxification processes play an important role in helping prevent exposure to the toxic and carcinogenic effect of mycotoxins (Bulent et al., 2006). Detoxification of mycotoxins is typically achieved by removal or elimination of the contaminated commodities or by inactivation of the toxins present in these commodities by physical, chemical, or biological methods (Sinha, 1998). It is generally accepted that mycotoxin levels in food needs to be reduced as low as technologically possible. Many physical, chemical and biological methods have been applied for the removal and biosynthesis of aflatoxins, and also growth of aflatoxigenic moulds inhibition. However, few of these have practical applications (Buser and Abbas, 2002; Luias et al., 2002).

Many methods have been applied in order to control or inhibit mould growth and maize contamination by aflatoxin, although strategies to control growth of mould and mycotoxin contamination has to be considered (Munkvold and Desjardin, 1997), for plants products postharvest methods are also recommended (Bankole and Adebanjo, 2003). The prevention of mycotoxin production includes all phases of food and feed production, because the mould contamination may occur in the field, during storage, as well as in transport. Adequate storage with optimal temperature and humidity of grains and relative humidity and the hygiene in silos may decrease the growth of toxicogenic moulds (Maja et al., 2002).

In order to control aflatoxins contamination, the coexisting fungi have been exploited by some earlier workers viz. roy and Chourasia, 1990; Choudhary and Sinha, 1993; Roy and Kumar, 1997; Shivendra and Awadh, 2001etc. Nanis et al., (2010) have studied the antifungal effect of five Lactobacillus strains namely $L$. plantarum ATCC 4008, $L$. plantarum 12006, Lactobacillus plantarum $299 \mathrm{~V}$, L. paracasei subsp. paracasei LMG 13552 and L.rhamnosus VT1exhibiting inhibition of growth and aflatoxin producing Aspergilli. The mechanism of inhibition of growth and aflatoxin production has been studied by Mehdi Razzaghi-Abyaneh (2011). Rattanaporn Thakaew and Hataichanoke Niamsup (2013) have studied the inhibitory Activity of Bacillus subtilis BCC 6327 Metabolites against Growth of Aflatoxigenic Fungi Isolated from Bird Chili Powder.

In the present investigation an attempt has been made to study the influence of microbial interactions on growth and aflatoxin production by a toxigenic strain of Aspergillus parasiticus in vitro.

\section{Materials and Methods}

The toxigenic strain of Aspergillus parasiticus NRRL-2999 was used to assay the growth performance and aflatoxin production in presence of other filamentous fungi. This strain (obtained from Northern regional Research Laboratory, North Carolina, USA had the capacity to produce aflatoxins B1, B2, $\mathrm{G} 1$, and $\mathrm{G} 2$ and were quantified as $8.34,6.87$, 7.34 and $2.32 \mathrm{mg} / \mathrm{ml}$ respectively.

\section{Isolation of fungi}

The interacting fungi used in the present investigation were isolated from cereal crops viz. wheat, rice and maize and identified by comparing with specimen cultures in the Mycology Department and then confirmed by Commonwealth Mycological Research Institute (CMI), Kew, London. The interacting fungi identified were Aspergillus niger, A. sydowi, Alternaria alternata, A. brassicae, Curvularia lunata, Geotrichum candidum, Monilia sitiphila, 
Helminthosporium sativum, Chaetomium globosum, Cladosporium herbarum, Fusarium moniliforme, Penicillium citrinum, Mucor mucido, Rhizopus nigricans and Rhizopus stolonifer.

\section{Dual culture}

Petri dishes containing Potato Dextrose Agar medium (PDA) were seeded equidistantly at four corner with sis days old mycelial inoculum of individual test fungus along with centrally seeded Aspergillus parasiticus NRRL2999. The inoculated plates were incubated at $28 \pm 2^{\circ} \mathrm{C}$ for ten days in BOD incubator under alternate cycles of $12 \mathrm{hrs}$. light and dark. After two days of incubation interacting behaviour was observed and recorded by method suggested by Johnson and Curl (1972) as follows:

A - A mutual intermingling of the two organisms.

B - Mutual inhibition on contact

C - Mutual inhibition at a distance

D - Inhibition on contact, the antagonist continues to grow, unchanged or reduced rate through the colony of the inhibited organisms.

E - Inhibition at a distance, the antagonist continues to grow resulting clear zone at an unchanged or reduced rate.

\section{Aflatoxin assay}

$1 \mathrm{ml}$ culture filtrate, grown in Czapek- dox liquid medium of each of the interacting fungi viz. Aspergillus niger, A. sydowi, Alternaria alternata, A. brassicae, Curvularia lunata, Geotrichum candidum, Monilia sitophila, Helminthosporium sativum, Chaetomium globosum, Cladosporium herbarum, Fusarium moniliforme, Penicillium citrinum,
Mucor mucido, Rhizopus nigricans and Rhizopus stolonifer having growth inhibitory ability in dual culture was supplemented separately in $250 \mathrm{ml}$ Erlen Mayer flask containing $50 \mathrm{ml}$ of SMKY liquid medium (Diener and Davis, 1966). Subsequently flasks were inoculated separately with $1 \mathrm{ml}$ spore suspension $\left(10^{6}\right.$ spores $\left./ \mathrm{ml}\right)$ of A. parasiticus NRRL2999 and kept for 10 days under controlled conditions in a BOD incubator.

The culture was then filtered through pre weighed filter paper and extraction was done with chloroform. The dried chloroform extracts were further subjected to Thin Layer Chromatography (TLC) for qualitative and quantitative estimations following the method of Reddy et al., (1970). Confermation of aflatoxins presence was made by trifluoroacetic acid (TFA) and 50\% aqueous sulphuric acid (Stach and Pohland, 1975).Amount of Aflatoxins produced was determined by spectrophotometer (CAMAG TLC scanner- II and DU- 64 spectrophotometer).

\section{Determination of growth}

After filtration, mycelial mat was dried at $60^{\circ} \mathrm{C}$ for $24 \mathrm{hrs}$ in an oven and weighed to determine the change in dry weight of $A$. parasiticus.

Data were statically analyzed by mean \pm S.E. The results obtained have been presented in tables 1, 2 and 3; Figs. 1 and 2.

\section{Results and Discussion}

All the fifteen types of interacting fungal associations with Aspergillus parasiticus NRRL2999 strain were found to inhibit aflatoxins B1, B2, G1 and G2 production but the intensity was variable (Table 1). In the dual culture of Aspergillus Parasiticus 
NRRL2999 with A. sydowi, A. niger, Geotrichum candidum and Monilia sitophila E type of interaction behaviour was recorded. A clear cut inhibition zone was developed and the growth of A. parasiticus significantly arrested. The inhibition zone was also found to be widened with the increase of incubation period. Alternaria alternata, A. brassicae and Helminthosporium sativum exhibited D type of interacting behaviour with Aspergillus parasiticus. Similarly Curvularia lunata, Chaetomium globosum and Penicillium citrinum exhibited B type and Cladosporium herbarum, Fusarium moniliforme, Mucor mucedo, Rhizopus stolonifer and $R$. nigricans A type of interacting behaviour with $A$. parasiticus NRRL2999 (Table 1).

From the results (Table 2: Fig. 1) it is evident that $1 \mathrm{ml}$ of culture filtrate of Alternaria alternata, A. brassicae, Helminthosporium sativum, Chaetomium globosum, Cladosporium herbarum, Fusarium moniliforme, Penicillium citrinum, Mucor mucedo, Rhizopus stolonifer and R. nigricans was found to be highly inhibitory to growth of A. parasiticus NRRL2999 that caused $57.47 \%$ to $76.55 \%$ inhibition (Table 2; Fig. 1).

Growth inhibition of $A$. parasiticus by Cladosporium herbarum and Fusarium moniliforme was highest, about 76.32$76.55 \%$ followed by Mucor mucedo, Rhizopus stolonifer and $R$. nigricans (71.72- 74.48\%) and Penicillium citrinum and Chaetomium globosum (67.35- 67.55\%). Aspergillus sydowi, A. niger and Curvularia lunata caused least growth inhibition of $A$. parasiticaNRRL2999. Geotricum candidum and Monilia sitophila caused only about $45 \%$ growth inhibition to A. parasitica.

Data recorded in table 3 and figure 2 reveals that Chaetomium globosum, Helminthosporium sativum, Cladosporium herbarum, Fusarium moniliforme, Mucor mucedo, Rhizopus stolonifer and $R$. nigricans caused maximum inhibition of aflatoxin B1 production by Aspergillus parasiticusNRRL2999 (91.84- 98.56\%) followed by Alternaria alternata, $A$. brassicae, Curvularia lunata (80.60\%, $86.40 \%$ and $84.70 \%$ respectively) and Aspergillus sydowi and A. niger (72.6 and73.0\% respectively). Gleotrichum candidum and Moinilia sitophila caused less inhibition og aflatoxin $\mathrm{B} 1$ production by $A$. parasitica (Table 3; Fig. 2). Aflatoxin B2 production by Aspergillus parasiticus NRRL2999 was strongly inhibited by culture filtrates of Gleotrichum candidum, Monilia sitophila, Helminthosporium sativum, Chaetomium globosum, Cladosporium herbarum and Penicillium citrinum (65.795$79 \%)$.

Similarly Alternaria alternata, A. brassicae, Curvularia lunata, Fusarium moniliforme, Mucor mucedo, Rhizopus stolonifer and $R$. nigricans caused 38.13-55.54\% aflatoxin B2 inhibition.

The culture filtrates of other fungi had less inhibitory action (Table 3; Fig. 2). Aflatoxin G1 production by A. parasiticu was maximaly inhibited by A. sydowi (86.105), and A. niger (86.14\%), followed by $M$. mucedo and $R$. nigricans (76.15\%), R.stolonifer (75.74\%) and A. alternata, A. brassicae, (66.62$67.98 \%)$. $H$. sativum, $C$. globosum, $F$. moniliforme and $C$. herbarum caused 60.82$62.39 \%$ inhibition to G1 production. Fusarium moniliforme caused $71.98 \%$ inhibition of aflatoxin G2 prodiction by $A$. parasiticus. Curvularia lunata, G. candidum, M. sitiphila, $H$. sativum, Chaetomium globosum, Cladosporium herbarum, $P$. citrinum, M. mucedo, $R$. stolonifer and $R$. nigricans caused moderate inhibition of aflatoxin G2 production by A. parasiticus about 55- 70\%. 
Table.1 Interacting behaviour of co- existing fungi with Aspergillus parasiticus in dual culture

\begin{tabular}{|l|l|l|l|l|l|}
\hline \multirow{2}{*}{ Interacting Fungi } & \multicolumn{5}{|l|}{ Type of interacting behaviour } \\
\cline { 2 - 7 } & $\mathrm{A}$ & $\mathrm{B}$ & $\mathrm{C}$ & $\mathrm{D}$ & $\mathrm{E}$ \\
\hline $\begin{array}{l}\text { Aspergillus } \\
\text { sydowi }\end{array}$ & - & - & - & - & + \\
\hline Aspergillus niger & - & - & - & - & + \\
\hline $\begin{array}{l}\text { Alternaria } \\
\text { alternata }\end{array}$ & - & - & - & + & - \\
\hline A. brassicae & - & - & - & + & - \\
\hline Curvularia lunata & & + & & & \\
\hline $\begin{array}{l}\text { Geotrichum } \\
\text { candidum }\end{array}$ & - & - & - & - & + \\
\hline Monilia sitophila & - & - & - & - & + \\
\hline $\begin{array}{l}\text { Helminthosporium } \\
\text { sativum }\end{array}$ & - & - & & + & \\
\hline $\begin{array}{l}\text { Chaetomium } \\
\text { globosum }\end{array}$ & - & + & - & - & - \\
\hline $\begin{array}{l}\text { Cladosporium } \\
\text { herbarum }\end{array}$ & + & - & - & - & - \\
\hline $\begin{array}{l}\text { Fusarium } \\
\text { moniliforme }\end{array}$ & + & - & - & - & - \\
\hline $\begin{array}{l}\text { Penicillium } \\
\text { citrinum }\end{array}$ & - & + & - & - & - \\
\hline Mucor mucido & + & - & - & - & - \\
\hline $\begin{array}{l}\text { Rhizopus } \\
\text { stolonifer }\end{array}$ & + & - & - & - & - \\
\hline $\begin{array}{l}\text { Rhizopus } \\
\text { nigricans }\end{array}$ & + & - & - & - & - \\
\hline
\end{tabular}

+ Sign indicates the type of interacting behavior, - Sign indicates no interaction

Table.2 Effect of culture filtrate of interacting fungi on growth of Aspergillus parasiticus NRRL 2999

\begin{tabular}{|l|l|l|}
\hline Interacting fungi & Growth in $\mathbf{~ m g}$ & Growth inhibition (\%) \\
\hline Aspergillus parasiticus NRRL 2999 as control & $\mathbf{2 1 7 5} \pm \mathbf{2 . 3 5}$ & \\
\hline Aspergillus sydowi & $\mathbf{1 5 3 5} \pm \mathbf{1 . 1 5}$ & $\mathbf{2 9 . 4 3}$ \\
\hline Aspergillus niger & $\mathbf{1 4 7 5} \pm \mathbf{1 . 1 7}$ & $\mathbf{3 0 . 3 5}$ \\
\hline Alternaria alternata & $\mathbf{8 8 5} \pm \mathbf{1 . 1 9}$ & $\mathbf{5 4 . 4 7}$ \\
\hline A. brassicae & $\mathbf{8 5 0} \pm \mathbf{1 . 1 3}$ & $\mathbf{5 9 . 0 8}$ \\
\hline Curvularia lunata & $\mathbf{1 4 3 5} \pm \mathbf{1 . 1 2}$ & $\mathbf{3 2 . 1 8}$ \\
\hline Geotrichum candidum & $\mathbf{1 1 5 5} \pm \mathbf{1 . 1 1}$ & $\mathbf{4 5 . 0 5}$ \\
\hline Monilia sitophila & $\mathbf{1 1 5 0} \pm \mathbf{1 . 1 7}$ & $\mathbf{4 5 . 2 8}$ \\
\hline Helminthosporium sativum & $\mathbf{8 5 0} \pm \mathbf{1 . 1 6}$ & $\mathbf{5 9 . 0 8}$ \\
\hline Chaetomium globosum & $\mathbf{6 6 5} \pm \mathbf{1 . 1 1}$ & $\mathbf{6 7 . 5 8}$ \\
\hline Cladosporium herbarum & $\mathbf{4 7 0} \pm \mathbf{1 . 1 0}$ & $\mathbf{7 6 . 5 5}$ \\
\hline Fusarium moniliforme & $\mathbf{4 7 5} \pm \mathbf{1 . 1 3}$ & $\mathbf{7 6 . 3 2}$ \\
\hline Penicillium citrinum & $\mathbf{6 7 0} \pm \mathbf{1 . 1 3}$ & $\mathbf{6 7 . 3 5}$ \\
\hline Mucor mucido & $\mathbf{5 1 5} \pm \mathbf{1 . 2 5}$ & $\mathbf{7 4 . 4 8}$ \\
\hline Rhizopus stolonifer & $\mathbf{5 5 0} \pm \mathbf{1 . 2 3}$ & $\mathbf{7 2 . 8 7}$ \\
\hline Rhizopus nigricans & $\mathbf{5 5 7} \pm \mathbf{1 . 1 7}$ & $\mathbf{7 1 . 7 2}$ \\
\hline
\end{tabular}


Table.3 Effect of culture filtrate of 15 interacting fungi on Aflatoxin production by Aspergillus parasiticus NRRL2999 strain

\begin{tabular}{|c|c|c|c|c|c|c|c|c|}
\hline \multirow[t]{2}{*}{ Interacting fungi } & \multicolumn{8}{|c|}{$\begin{array}{l}\text { Aflatoxin production by } A \text {. parasiticus NRRL2999 in presence of } 15 \text { interacting } \\
\text { fungi }\end{array}$} \\
\hline & B1 & $\begin{array}{l}\% \\
\text { inhibiti } \\
\text { on }\end{array}$ & B2 & $\begin{array}{l}\% \\
\text { inhibiti } \\
\text { on }\end{array}$ & G1 & $\begin{array}{l}\% \\
\text { inhibiti } \\
\text { on }\end{array}$ & G2 & $\begin{array}{l}\% \\
\text { inhibiti } \\
\text { on }\end{array}$ \\
\hline $\begin{array}{l}\text { Aspergillus } \\
\text { parasiticus NRRL2 } \\
999 \text { as control }\end{array}$ & $\begin{array}{l}8.34 \pm 0 . \\
16\end{array}$ & & $\begin{array}{l}6.87 \pm 0 . \\
12\end{array}$ & & $\begin{array}{l}7.34 \pm 0 . \\
16\end{array}$ & & $\begin{array}{l}2.32 \pm 0 \\
12\end{array}$ & \\
\hline Aspergillus sydowi & $\begin{array}{l}2.28 \pm 0 . \\
17\end{array}$ & 72.6 & $\begin{array}{l}5.52 \pm 0 . \\
16\end{array}$ & 19.65 & $\begin{array}{l}1.02 \pm 0 . \\
12\end{array}$ & 86.10 & $\begin{array}{l}2.04 \pm 0 . \\
11\end{array}$ & 12.06 \\
\hline Aspergillus niger & $\begin{array}{l}2.25 \pm 0 . \\
14\end{array}$ & 73.0 & $\begin{array}{l}5.35 \pm 0 . \\
13\end{array}$ & 22.12 & $\begin{array}{l}1.06 \pm 0 \text {. } \\
13\end{array}$ & 85.14 & $\begin{array}{l}2.08 \pm 0 . \\
12\end{array}$ & 10.34 \\
\hline $\begin{array}{l}\text { Alternaria } \\
\text { alternata }\end{array}$ & $\begin{array}{l}1.62 \pm 0 . \\
18\end{array}$ & 80.6 & $\begin{array}{l}4.25 \pm 0 \text {. } \\
16\end{array}$ & 38.13 & $\begin{array}{l}2.35 \pm 0 \\
14\end{array}$ & 67.98 & $\begin{array}{l}1.75 \pm 0 . \\
16\end{array}$ & 24.56 \\
\hline A. brassicae & $\begin{array}{l}1.14 \pm 0 . \\
16\end{array}$ & 86.4 & $\begin{array}{l}3.75 \pm 0 . \\
15\end{array}$ & 45.41 & $\begin{array}{l}2.45 \pm 0 . \\
16\end{array}$ & 66.62 & $\begin{array}{l}1.71 \pm 0 . \\
11\end{array}$ & 26.29 \\
\hline Curvularia lunata & $\begin{array}{l}1.28 \pm 0 . \\
16\end{array}$ & 84.7 & $\begin{array}{l}3.65 \pm 0 . \\
11\end{array}$ & 46.87 & $\begin{array}{l}3.51 \pm 0 \text {. } \\
15\end{array}$ & 51.36 & $\begin{array}{l}1.05 \pm 0 . \\
16\end{array}$ & 54.74 \\
\hline $\begin{array}{l}\text { Geotrichum } \\
\text { candidum }\end{array}$ & $\begin{array}{l}5.65 \pm 0 . \\
17\end{array}$ & 32.25 & $\begin{array}{l}2.21 \pm 0 \\
13\end{array}$ & 673.83 & $\begin{array}{l}4.25 \pm 0 \\
16\end{array}$ & 42.09 & $\begin{array}{l}0.75 \pm 0 \\
16\end{array}$ & 67.67 \\
\hline Monilia sitophila & $\begin{array}{l}6.85 \pm 0 . \\
12\end{array}$ & 17.86 & $\begin{array}{l}2.25 \pm 0 . \\
14\end{array}$ & 67.25 & $\begin{array}{l}4.50 \pm 0 . \\
12\end{array}$ & 38.69 & $\begin{array}{l}0.70 \pm 0 . \\
05\end{array}$ & 69.82 \\
\hline $\begin{array}{l}\text { Helminthosporium } \\
\text { sativum }\end{array}$ & $\begin{array}{l}0.68 \pm 0 . \\
16\end{array}$ & 91.84 & $\begin{array}{l}1.45 \pm 0 . \\
16\end{array}$ & 78.89 & $\begin{array}{l}2.76 \pm 0 \\
16\end{array}$ & 62.39 & $\begin{array}{l}1.03 \pm 0 . \\
07\end{array}$ & 55.60 \\
\hline $\begin{array}{l}\text { Chaetomium } \\
\text { globosum }\end{array}$ & $\begin{array}{l}0.12 \pm 0 \\
14\end{array}$ & 98.56 & $\begin{array}{l}1.75 \pm 0 . \\
17\end{array}$ & 74.52 & $\begin{array}{l}2.85 \pm 0 \\
10\end{array}$ & 61.17 & $\begin{array}{l}1.03 \pm 0 \\
05\end{array}$ & 55.60 \\
\hline $\begin{array}{l}\text { Cladosporium } \\
\text { herbarum }\end{array}$ & $\begin{array}{l}0.14 \pm 0 . \\
16\end{array}$ & 98.32 & $\begin{array}{l}1.77 \pm 0 . \\
15\end{array}$ & 74.23 & $\begin{array}{l}2.87 \pm 0 \\
10\end{array}$ & 60.89 & $\begin{array}{l}1.05 \pm 0 . \\
06\end{array}$ & 54.74 \\
\hline $\begin{array}{l}\text { Fusarium } \\
\text { moniliforme }\end{array}$ & $\begin{array}{l}0.20 \pm 0 . \\
16\end{array}$ & 97.60 & $\begin{array}{l}3.26 \pm 0 . \\
16\end{array}$ & 55.54 & $\begin{array}{l}2.86 \pm 0 \\
11\end{array}$ & 61.03 & $\begin{array}{l}0.65 \pm 0 . \\
06\end{array}$ & 71.98 \\
\hline $\begin{array}{l}\text { Penicillium } \\
\text { citrinum }\end{array}$ & $\begin{array}{l}1.34 \pm 0 . \\
16\end{array}$ & 83.93 & $\begin{array}{l}2.35 \pm 0 \\
13\end{array}$ & 35.79 & $\begin{array}{l}3.25 \pm 0 \\
13\end{array}$ & 55.72 & $\begin{array}{l}0.75 \pm 0 \\
04\end{array}$ & 67.67 \\
\hline Muсог тисіdo & $\begin{array}{l}0.15 \pm 0 . \\
13\end{array}$ & 98.20 & $\begin{array}{l}3.50 \pm 0 . \\
16\end{array}$ & 49.09 & $\begin{array}{l}1.75 \pm 0 . \\
16\end{array}$ & 76.15 & $\begin{array}{l}0.76 \pm 0 . \\
06\end{array}$ & 67.24 \\
\hline Rhizopus stolonifer & $\begin{array}{l}0.18 \pm 0 . \\
12\end{array}$ & 97.84 & $\begin{array}{l}3.45 \pm 0 \\
16\end{array}$ & 48.32 & $\begin{array}{l}1.78 \pm 0 \\
14\end{array}$ & 75.74 & $\begin{array}{l}0.77 \pm 0 . \\
06\end{array}$ & 66.80 \\
\hline Rhizopus nigricans & $\begin{array}{l}0.17 \pm 0 . \\
11\end{array}$ & 97.96 & $\begin{array}{l}3.43 \pm 0 . \\
12\end{array}$ & 48.03 & $\begin{array}{l}1.75 \pm 0 . \\
16\end{array}$ & 76.15 & $\begin{array}{l}0.75 \pm 0 \\
07\end{array}$ & 67.67 \\
\hline
\end{tabular}


Fig.1 Growth inhibition of Aspergillus parasiticus NRRL 2999 strain in presence of 15 interacting fungi

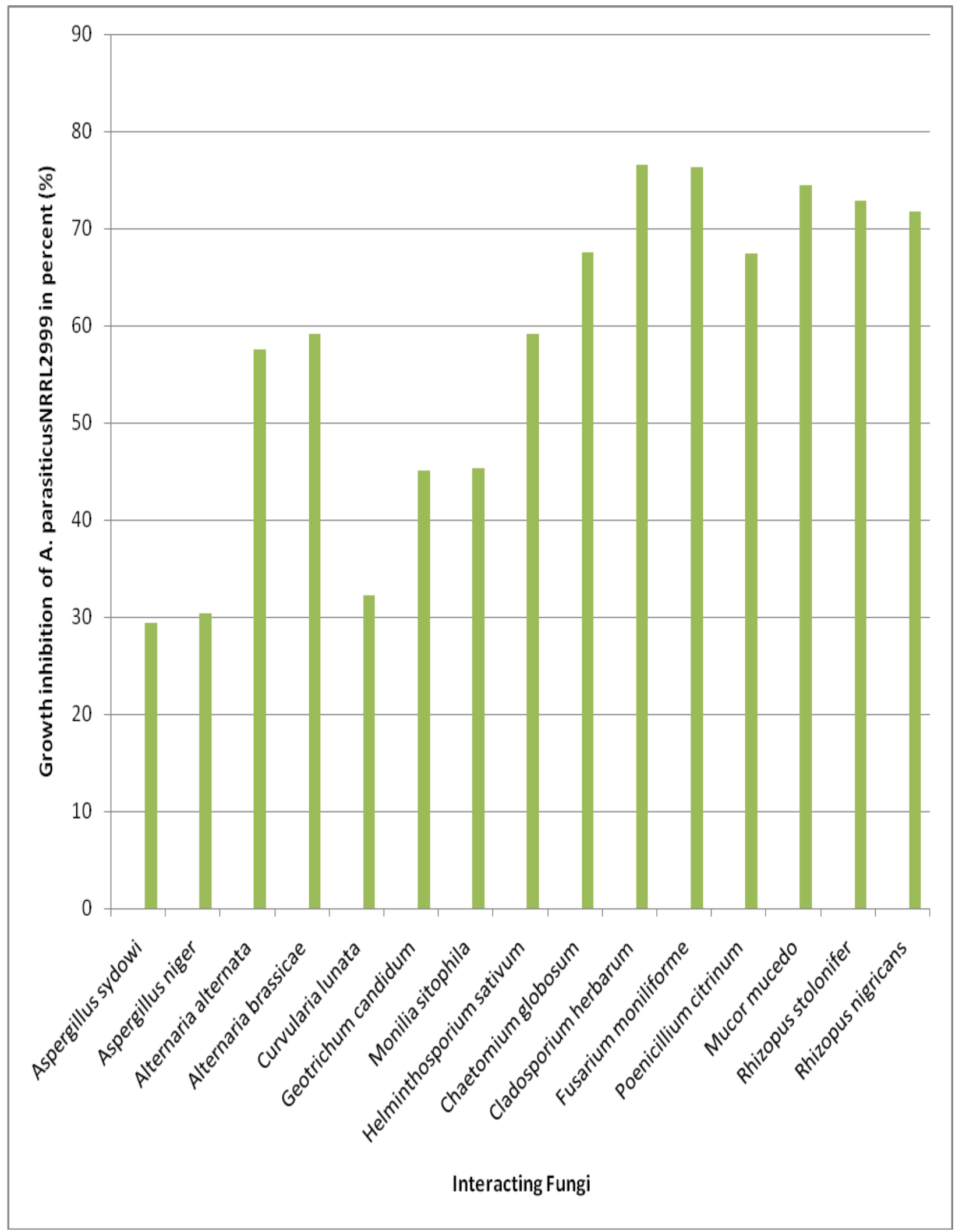


Fig.2 Inhibition of aflatoxin production in percent in presence of interacting fungi

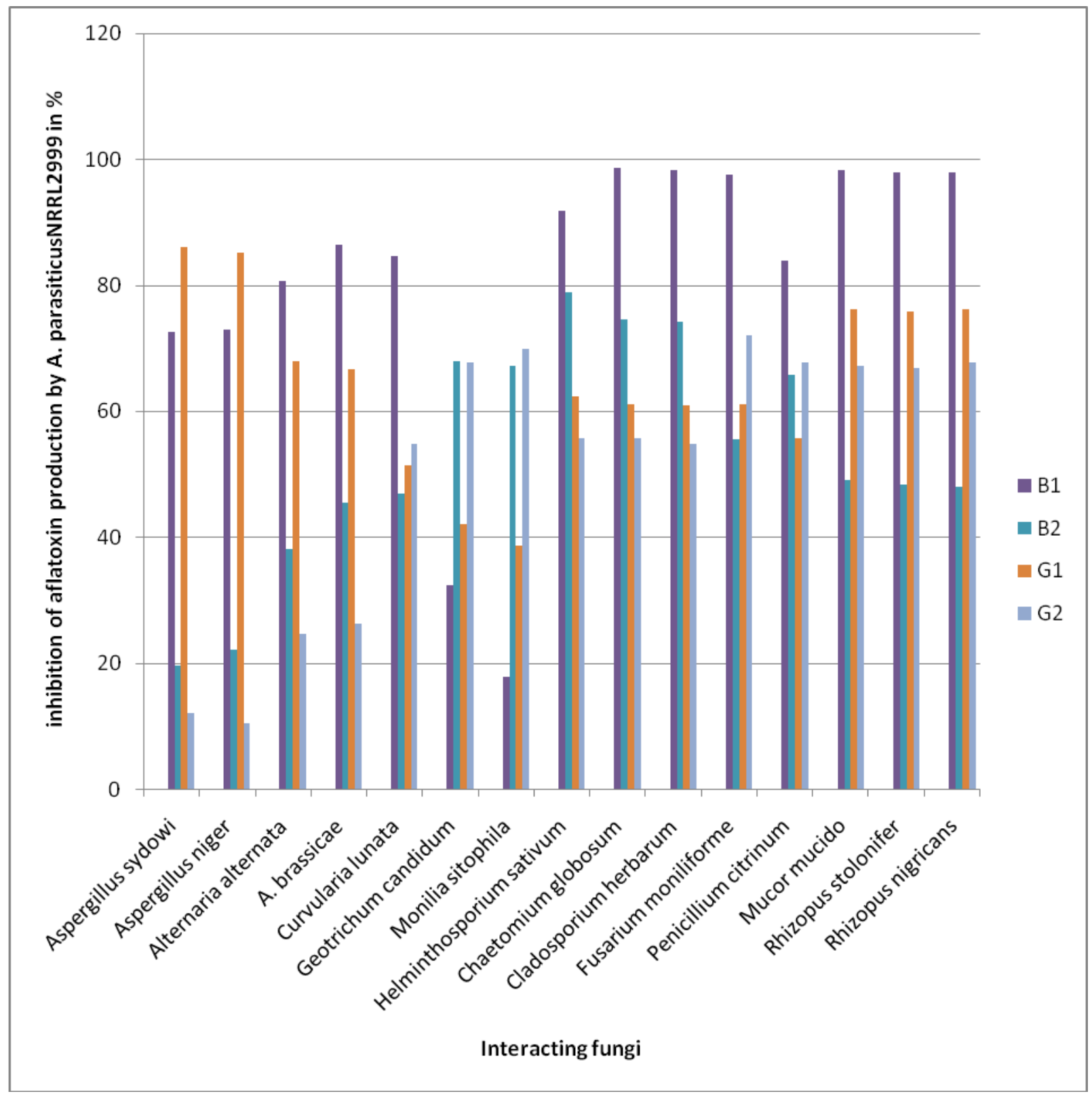

The results confirm that the interacting fungi viz. Aspergillus niger, A. sydowi, Alternaria alternata, A. brassicae, Curvularia lunata, Geotrichum candidum, Monilia sitophila, Helminthosporium sativum, Chaetomium globosum, Cladosporium herbarum, Fusarium moniliforme, Penicillium citrinum, Mucor mucido, Rhizopus nigricans and Rhizopus stolonifer are the best biological agents to inhibit growth and Aflatoxin production ability of Aspergillus parasiticus NRRL2999 strain. The present findings are in agrement with the work of Roy and Kumar (1997), Chehal and Chehal (1993), Shivendra Kumar and Awadh K. Roy (2001) and Amer et al., (1997) who have also noticed similar response of the inhibition. Inhibition of aflatoxin production has been observed in Aspergillus flavus when this was coinoculated with $A$. niger (Tsubouchi et 
al., 1980; Wicklow et al., 1980). Degradation of aflatoxin B1 by $A$. niger and Corynebacterium rubrum has also been analysed by adding the $\mathrm{C}^{14}$ - labelled aflatoxinB1 to culture of these microorganisms (Mann and Rehm, 1977). Inhibition of fungal growth and Aflatoxin B1 production in Aspergillus parasiticus by Lactobacillus strains viz. L. plantarum ATCC 4008, L. plantarum 12006, Lactobacillus plantarum 299V, L. paracasei subsp. paracasei LMG 13552 and L.rhamnosus VT1has been studied by Gomah Nanis H.et al.,(2009).

Similar results have been reported by other investigators. Antifungal activities by Lactobacillus species that inhibited both the growth and the aflatoxins production of $A$. parasiticus has been reported by Vanne, et al., (2000) and Onilud, et al., (2005).

Also, Coallier- Ascah and Idziak (1985) found that the inoculation of A. flavus spores into a culture of Streptococcus lactis in synthetic broth medium resulted in little or no aflatoxin accumulation even though the growth of the fungus was not hindered.

In general, it is suggested that such inhibitory response in Aspergillus parasiticus NRRL2999 is possibly due to antibiosis which might be accomplished by secretion of active metabolites by interacting fungi that inhibit growth and aflatoxin production. If, the active substances of these interacting fungi are chemically characterised, that would be a potential measure in the biological control of aflatoxin hazards.

\section{Acknowledgement}

Authors are thankful to Dr. Jainendra Kumar, Professor, Department of Botany and Biotechnology for providing necessary suggestions.

\section{References}

Amer GA, R. Aggarwal, DV Singh and K D Srivastava (1997): Interaction of Bacillus thuringinensis with Pythium ultimum and Fusarium oxusporum f. sp. Lycopersici: biological control. Curr Sci 73 (3), 284286

Bankole SA, Adebanjo A (2003). Mycotoxins in food in West Africa: current situation and possibilities of controlling it. African Journal of Biotechnology, 2: 254 - 263.

Bulent K, Alan DW, IS ILV (2006). Strategies to Prevent Mycotoxin Contamination of Food and Animal Feed: A Review. Critical Review of Food Science and Nutrition, 46: 593-619.

Buser MD, Abbas HK (2002). Effects of extrusion temperature and dwell time on aflatoxin levels in cottonseed. Journal of Agricultural and Food Chemistry, 50: 2556 - 2559.

Choudhary A K and K K Sinha (1993): Competition between a toxigenic Aspergillus flavus strain and other fungi on stored maize kernels. J. Stored Product Res, 29 (1), 75- 80.

Chehal VPS and PPK Chehal (1993): Bacillus thuringinensis as biocontrol agent for nematode- fungal disease complex of tomato. $6^{\text {th }}$ Int Cong of Plant Pathol, Montreal, Canada

Coallier-Ascah J. and Idziak, E.S. 1985. Interaction between Streptococcus lactis and Aspergillus flavus on production of aflatoxin. Appl. Environ. Microbiol. 49: $163-167$.

Diener U L and N D Davis (1996): Aflatoxin production by isolates of Aspergillus flavus. Phytopathology, 56, 1390- 1393

Johnson B F and E A Curl (1972): Method for research on the ecology of soil borne plant pathogens. Burgers Publication Co., Minneapolis M N Canada, pp. 178

Luias A, Rita S, Armando VN (2002). Journal of Agricultural and Food Chemistry, 50: 7493.

Maja P, Ana-Marija D, Željko J, Bogdan C (2002). Prevention of exposure to mycotoxins from food and feed.ArhHigRadaToksikol, 5: 229 -237.

Mann R and HJ Rehm (1977): Degradation products from aflatoxin B1 by 
Corynebacterium rubrum, Aspergillus niger, Trichoderma viride and Mucor ambigus. Eur J Appl Microbiol 2, 297- 299

Mehdi Razzaghi-Abyaneh, Masoomeh ShamsGhahfarokhi and Perng-Kuang Chang (2011). Aflatoxins: Mechanisms of Inhibition by Antagonistic Plants and Microorganisms, Aflatoxins - Biochemistry and Molecular Biology, Dr. Ramon G. Guevara-Gonzalez (Ed.), ISBN: 978-953307-395-8, InTech, Available from: http://www.intechopen.com/books/aflatoxin s-biochemistry-and-molecularbiology/aflatoxins-mechanisms-

ofinhibition- by-antagonistic-plants-andmicroorganisms

Munkvold GP, Desjardin AE (1997). Fumonisins in maize: can we reduce their occurrence. Plant Disease, 81: 556 - 565.

Nanis H. Gomah, W.S. Ragab and L. B. Bullerman (2010): Inhibition of Fungal Growth and Aflatoxin B1 Production by Some Lactobacillus Strains, Assiut J. of Agric. Sci., 40 (4)(27-36)

Onilude, A.A., Fagade, O.E.; Bello, M.M. and Fadahuns, I.F. 2005. Screening of the antifungal effects of Lactic Acid bacteria against toxigenic Penicillium and Aspergillus strains. In http://www.vtt./bel/2000micro biology/ antifungal attributes of lactic acid bacteria.

Rattanaporn Thakaew and Hataichanoke Niamsup (2013): Inhibitory Activity of Bacillus subtilis BCC 6327 Metabolites against Growth of Aflatoxigenic Fungi Isolated from Bird Chili Powder, International Journal of Bioscience, Biochemistry and Bioinformatics, Vol. 3, No. 1, 27- 32

Reddy $\mathrm{T}$ V, L. Vishwanathan and $\mathrm{T} A$ Venkitasubramanian (1970): Thin Layer Chromatography of Aflatoxin. Analytical
Biochem 38, 568- 571

Roy A. K and HK Chourasia (1990): Inhibition of aflatoxin production by microbial interaction, J. Gen Appl Microbiol, 36: 5962

Roy A. K and S Kumar (1997): Microbes for the prevention of aflatoxin contamination in herbal medicines. In Phytodiversification and Human welfare Eds. A K Roy, JVV Dogra and S K Verma. M D Publication, New Delhi, pp 27- 34

Shivendra Kumar and Awadh K. roy (2001): Inhibition of growth and aflatoxin production of Aspergillus parasiticus speare by co- existing fungi in vitro, $J$. Indian bot Soc, 80, 149- 151.

Sinha KK (1998). Detoxification of mycotoxin and food safety. In: Sinha KK and Batnagar D Eds., Mycotoxins in Agriculture and food safety. Mercel Dekker, Inc., (New York) 381- $405 \mathrm{p}$.

Stach M E and A E Pohland (1975): Collaborative study of a method for chemical confermation of identification of Aflatoxins. J. Assoc off Anal Chem 58, 110113

Tsubouchi H, K Yamamofo, K. Hisada, Y Sakabe and Suchihira (1980): Degradation of aflatoxin B1 by Aspergillus niger. Proc Jpn Assoc Mycotoxicol 12, 33- 35

Vanne, L., Kleemola, T. and Haikara, A. 2000. Inhibition of aflatoxin-producing aspergilli by lactic acid bacteria isolates from indigenously fermentedcereal gruels African Journal of Biotechnology 4, 12: 1404- 1408

Wicklow D T, C W hesseltine, O L Shotwell and G L Adams (1980): Interference, competition and aflatoxin levels in corn. Phytopathol 70, 761- 764

\section{How to cite this article:}

Byas Kumar, Baidyanath Kumar, Soniya Bharti and Jainendra Kumar. 2017. Effect of Coexisting Filamentous Fungi on Growth Inhibition and Aflatoxin production by Aspergillus parasiticus. Int.J.Curr.Microbiol.App.Sci. 6(8): 2789-2799.

doi: https://doi.org/10.20546/ijcmas.2017.608.332 